\title{
KARAKTERISTIK FISIKOKIMIA TEPUNG KORO PEDANG (Canavalia ensiformis) TERMODIFIKASI DENGAN VARIASI KONSENTRASI ASAM LAKTAT DAN LAMA PERENDAMAN
}

\author{
Physicochemical Characteristic of Modified Jack Bean (Canavalia ensiformis) Flour with Various Lactic \\ Acid Concentration and Soaking Time
}

\section{Achmad Ridwan Ariyantoro, Dian Rachmawanti, Imro'ah Ikarini}

\author{
Program Studi Ilmu danTeknologi Pangan, Universitas Sebelas Maret, Surakarta, \\ Jl. Ir. Sutami 36 A, Kentingan, Surakarta, 57126 \\ Email: ridwan030586@gmail.com
}

\begin{abstract}
ABSTRAK
Penelitian ini bertujuan untuk mengetahui karakteristik fisikokimia tepung koro pedang (Canavalia ensiformis) termodifikasi yang dihasilkan dari pemberian perlakuan asam laktat berbagai konsentrasi dan lama perendaman. Penelitian ini menggunakan rancangan acak faktorial dengan dua faktor yaitu konsentrasi asam laktat $(0,5 \%$, $1 \%$, 1,5\%) dan lama perendaman (30 menit dan 60 menit) dengan 3 kali ulangan sampel dan 2 kali ulangan analisis. Hasil penelitian menyatakan bahwa semakin besar konsentrasi asam laktat dan semakin lama waktu perendaman cenderung meningkatkan kandungan amilosa, daya serap air, kelarutan, swelling power, dan derajat putih tepung koro pedang termodifikasi, namun menurunkan kadar air dan kadar protein tepung koro pedang termodifikasi.
\end{abstract}

Kata kunci: Koro pedang, modifikasi, asam laktat, lama perendaman, fisikokimia

\begin{abstract}
This study was aimed to investigated physicochemical characteristic of modified jack bean flour (Canavalia ensiformis) with various lactic acid concentration and soaking time. This study used factorial random design with two factors: lactic acid concentration $(0.5 \%, 1 \%, 1.5 \%)$ and soaking time $(30$ and 60 minutes) with three sample repetition and two analysis repetition. The result of study showed that increased lactic acid concentration and soaking time could increased amylose content, water absorption capacity, solubility, swelling power, and whiteness degree of jack bean flour modified, but decereased the moisture content and protein content of jack bean flour modified.
\end{abstract}

Keywords: Jack bean, modified flour, lactic acid, soaking time, physicochemical

\section{PENDAHULUAN}

Konsumsi tepung terigu yang semakin meningkat mengakibatkan pemerintah meningkatkan impor terigu. Berdasarkan data Disperindag, angka konsumsi terigu masyarakat Indonesia tahun 2010 mencapai 4,3 juta ton dan pada tahun 2011 naik mencapai 4,6 juta ton. Sekarang sudah saatnya untuk mencari sebuah alternatif tepung berdasarkan produk lokal yang dimiliki Indonesia, alternatif produk lokal tersebut misalnya koro pedang.

Koro pedang (Canavalia ensiformis) merupakan bahan lokal Indonesia, yang belum banyak pemanfaatannya. Pada tahun 2010-2011 tercatat dari lahan seluas $24 \mathrm{Ha}$ di
12 kabupaten di Jawa Tengah telah menghasilkan 216 ton koro pedang setiap panen (Kabupaten Blora, Banjarnegara, Temanggung, Pati, Kebumen, Purbalingga, Boyolali, Batang, Cilacap, Banyumas, Magelang, dan Jepara) (Dakornas, 2012). Koro pedang tumbuh baik pada ketinggian 20 sampai $2000 \mathrm{~m}$ dpl, koro pedang tergolong mudah untuk beradaptasi dengan kondisi lingkungannya sehingga tanaman ini cenderung tidak memerlukan banyak perawatan. Selain mudah dalam hal pembudidayaan, kandungan proteinnya diketahui sebesar 18-25\%, dengan kadar lemak antara 0,2-3,0\%, dan kandungan karbohidrat sebesar 50-60\% (Van Der Mesen dan Somaatmadja, 1993). 
Dalam praktiknya, ada beberapa masyarakat yang sudah menjadikan koro pedang menjadi tepung. Namun dalam kondisi ini, masih banyak memiliki kekurangan, tepung koro pedang yang diproduksi dan digunakan dalam pembuatan cookies koro, memiliki karakteristik yang kurang mengembang, kurang mengikat air, kerenyahan yang rendah, dan cookies yang dihasilkan dari tepung koro pedang memiliki bau yang tidak disukai oleh panelis (Mulyono, 2012). Oleh karena itu, diperlukan peningkatan kualitas tepung koro pedang, agar lebih baik, sehingga bisa dimanfaatkan untuk bahan baku pembuatan makanan. Upaya perbaikan kualitas tepung koro pedang dapat dilakukan dengan melakukan modifikasi sifat-sifat fungsionalnya.

Metode modifikasi yang paling banyak digunakan dalam pembuatan tepung adalah modifikasi secara kimia. Modifikasi tepung secara kimia umum dilakukan dengan alasan membutuhkan biaya yang rendah, waktu yang diperlukan singkat, dan metode yang digunakan lebih mudah sehingga metode ini direkomendasikan untuk industri pangan (Yanuwardana dkk., 2012).

Modifikasi dilakukan dengan cara menghidrolisa pati yang terdapat dalam tepung dengan menggunakan asam pada suhu dibawah gelatinisasi, sekitar $45^{\circ} \mathrm{C}$. Reaksinya adalah pemotongan ikatan $\dot{\alpha}-1,4$ glikosidik dari amilosa dan $\dot{\alpha}-1,6$ glikosidik dari amilopektin, sehingga ukuran molekul menjadi lebih rendah dan meningkatkan kecenderungan pasta untuk membentuk gel (Alsuhendra dan Ridawati, 2009). Dengan pemberian perlakuan konsentrasi asam laktat dan lama perendaman diharapkan dapat meningkatkan kualitas tepung koro pedang termodifikasi dalam karakteristik fisik (derajat putih), kimia (kadar air, kadar protein, kadar amilosa) dan fisikokimia (swelling power, daya serap air dan kelarutan).

\section{METODE PENELITIAN}

\section{Bahan}

Bahan dasar pembuatan tepung koro pedang termodifikasi adalah koro pedang (Canavalia ensiformis) dari Pasar Legi Solo dan larutan asam laktat dari Toko Bahan Kimia Lokal Solo. Bahan kimia untuk analisis antara lain aquades, $\mathrm{NaOH} 1 \mathrm{~N}$, asam asetat $1 \mathrm{~N}$, iod, ethanol 95\%.

\section{Alat}

Alat yang digunakan dalam pembuatan tepung koro pedang termodifikasi yaitu pisau, panci, blender, cabinet dryer (TEW Tipe IL-80EN) neraca analitik, dan gelas ukur. Alat untuk analisis fisikiokima antara lain oven (Memmert), neraca analitik (Ohaus Adventurer ${ }^{\mathrm{TM}}$ ), desikator, water bath, kertas saring, Spektrofotometer UV-Vis mini, dan alat-alat gelas.

\section{Tahapan Penelitian}

Tahapan penelitian diawali dengan perendaman koro pedang selama 72 jam dan dilakukan pergantian air setiap 6 jam sekali. Pengecilan ukuran koro pedang dengan cara perajangan. Koro pedang rajang direndam dalam larutan asam laktat $0,5 \%, 1 \%$, dan $1,5 \%$ selama 30 menit dan 60 menit dalam waterbath pada suhu $45^{\circ} \mathrm{C}$. Pengeringan koro pedang menggunakan cabinet dryer pada suhu $60^{\circ} \mathrm{C}$ selama 7 jam. Koro pedang kering selanjutnya ditepungkan dan diayak dengan ayakan 80 mesh. Selanjutnya dianalisis fisik, kimia, dan fisikokimia yang meliputi derajat putih, kadar air, amilosa, protein, daya serap air, kelarutan, dan swelling power.

\section{Kadar Air dan Derajat Putih}

Kadar air diukur dengan menggunakan metode Thermogravimetri (Sudarmadji dkk., 1997). Pengukuran derajat putih atau intensitas warna, menggunakan alat Minolta Chromameter seri 400 (CR-400) dengan metode Hunter Lab menurut deMan, (1999). Chromameter dikalibrasi dengan standar warna putih lalu tepung dimasukkan dalam kuvet. Selanjutnya, mengukur nilai L, a, b. Hasil yang diperoleh dihitung dengan rumus: $\left.\mathrm{W}=100[100-1]^{2}+\left(\mathrm{a}^{2}+\mathrm{b}^{2}\right)\right]^{0,5}$

\section{Kadar Protein dan Kadar Amilosa}

Pengukuran kadar protein dengan menggunakan metode Kjeldahl (Sudarmadji dkk., 1997). Sedangkan, kadar amilosa menggunaka metode Aliawati (2003), $100 \mathrm{mg}$ sampel tepung dimasukkan ke dalam labu takar dan ditambahkan $1 \mathrm{ml}$ etanol serta $9 \mathrm{ml} \mathrm{NaOH} 1 \mathrm{~N}$. Setelah itu, larutan sampel dipanaskan selama 10 menit kemudian didinginkan dan dipindahkan ke dalam labu takar $100 \mathrm{ml}$, kemudian ditetapkan sampai tanda tera dengan akuades. Larutan kemudian dipipet sebanyak $5 \mathrm{ml}$, lalu dimasukkan ke dalam labu takar $100 \mathrm{ml}$ dan ditambahkan $2 \mathrm{ml}$ larutan iod serta $1 \mathrm{ml}$ asetat $0,5 \mathrm{~N}$.

Larutan selanjutnya ditambah akuades sampai tanda tera, dikocok, didiamkan selama 20 menit, dan diukur intensitas warna dengan spektrofotometer. Kadar amilosa dihitung dengan rumus:

Amilosa (\%) = A/S x FP/w x 100\%

Keterangan:

$\mathrm{A}=$ absorbansi sampel

$\mathrm{S}=$ slope kemiringan pada kurva standar

$\mathrm{FP}=$ faktor pengenceran, yaitu 20

$\mathrm{W}=$ berat sampel (gram)

\section{Swelling Power}

Pengujian swelling power dilakukan menurut (Leach dkk., 1959), sebanyak 0,1 gr pati dilarutkan dalam aquadest $10 \mathrm{ml}$. Kemudian larutan dipanaskan dalam waterbath dengan temperatur $60^{\circ} \mathrm{C}$ selama 30 menit. Supernatant dipisahkan 
dengan sentrifuse dengan kecepatan $2500 \mathrm{rpm}$ selama 15 menit, dan ditimbang. Perhitungan swelling power dilakukan dengan rumus : berat pasta/ berat sampel kering.

\section{Daya Serap Air dan Kelarutan}

Pengukuran daya serap air menggunakan metode Fardiaz (1992), sampel 3 gr diletakkan pada kertas saring yang berada di atas corong, aquades ditambahkan sebanyak $11 \mathrm{ml}$, air yang menetes ditampung, lalu timbang air yang tertmpung dalam erlenmyer dan kertas saring. Daya serap air dihitung dengan rumus : berat air yang terserap/berat sampel. Sedangkan uji kelarutan menggunakan metode Apriyantono dkk. (1989).

\section{Rancangan Percobaan}

Rancangan percobaan menggunakan Rancangan Acak Lengkap Faktorial (RALF), dua faktor yaitu konsentrasi asam laktat dan lama perendaman, dengan 3 kali ulangan sampel dan 2 kali ulangan analisis. Data yang diperoleh akan dianalisis menggunakan analisis varian dengan menggunakan SPSS ver. 16. Jika terdapat perbedaan nyata antarperlakuan, maka akan dilanjutkan dengan uji beda nyata dengan metode Duncan's Multiple Range Test (DMRT) pada taraf signifikansi $\alpha=0,05$.

\section{HASIL DAN PEMBAHASAN}

\section{Kadar Air}

Kadar air yang berbeda nyata dengan kontrol terdapat pada konsentrasi asam laktat $1,5 \%$. Pada tepung dengan konsentrasi asam laktat $0,5 \%$ dan $1 \%$ tidak menunjukkan kadar air yang beda nyata terhadap kontrol (Tabel 1). Penurunan kadar air pada tepung koro pedang termodifikasi diduga karena asam laktat mampu melemahkan ikatan hidrogen. Ikatan hidrogen yang lemah menyebabkan berat molekul pati menjadi lebih rendah, strukturnya menjadi renggang dan lunak, sehingga saat pengeringan air yang teruapkan lebih banyak.

Semakin lama perendaman dengan asam laktat maka kadar air tepung yang dihasilkan semakin rendah (Tabel 2). Hal ini terjadi karena semakin lama reaksi dengan asam laktat menyebabkan ikatan hidrogen pada pati menjadi lemah, sehingga ikatan antar molekul air dengan berbagai komponen lainnya pada bahan lebih mudah putus. Menurut Harijono dkk. (2008), putusnya ikatan air dengan komponen lain mengakibatkan tekstur bahan menjadi berpori sehingga penguapan air selama pengeringan menjadi semakin mudah, dengan demikian kadar air akan menurun dalam jangka waktu pengeringan yang sama.

\section{Derajat Putih}

Derajat putih tepung koro pedang termodifikasi mengalami peningkatan seiring dengan bertambahnya konsentrasi asam laktat (Tabel 1). Koro pedang mengalami pencoklatan enzimatis selama proses pengolahan. Pencoklatan enzimatis disebabkan karena adanya enzim fenolase. Semakin lama waktu perendaman juga menunjukkan peningkatan derajat putih yang nyata (Tabel 2). Semakin tinggi konsentrasi asam laktat yang digunakan dan semakin lama perendaman menyebabkan penurunan $\mathrm{pH}$ larutan, pada $\mathrm{pH}$ yang rendah aktifitas enzim fenolase mampu dihambat sehingga derajat putih tepung akan meningkat.

Tabel 1. Pengaruh variasi konsentrasi asam laktat terhadap kadar air, derajat putih, kadar protein dan kadar amilosa tepung koro pedang termodifikasi

\begin{tabular}{lllll}
\hline Asam laktat & Kadar air $(\% \mathrm{wb})$ & Derajat putih $(\%)$ & Kadar protein $(\%)$ & Kadar amilosa (\%) \\
\hline $0 \%$ (kontrol) & $7,701 \% \pm 0,185^{\mathrm{b}}$ & $85,757 \pm 0,407^{\mathrm{a}}$ & $28,947 \pm 0,567^{\mathrm{b}}$ & $25,276 \pm 0,182^{\mathrm{a}}$ \\
$0,5 \%$ & $7,545 \% \pm 0,235^{\mathrm{b}}$ & $86,944 \pm 0,631^{\mathrm{b}}$ & $25,828 \pm 1,591^{\mathrm{a}}$ & $27,462 \pm 0,675^{\mathrm{b}}$ \\
$1 \%$ & $7,690 \% \pm 0,469^{\mathrm{b}}$ & $87,462 \pm 0,451^{\mathrm{c}}$ & $25,140 \pm 1,037^{\mathrm{a}}$ & $27,651 \pm 1,073^{\mathrm{b}}$ \\
$1,5 \%$ & $6,719 \% \pm 0,178^{\mathrm{a}}$ & $87,751 \pm 0,454^{\mathrm{c}}$ & $24,557 \pm 1,581^{\mathrm{a}}$ & $27,816 \pm 0,803^{\mathrm{b}}$ \\
\hline
\end{tabular}

Keterangan: angka yang diikuti huruf yang sama menunjukkan tidak berbeda nyata pada taraf signifikansi $\alpha=0,05$

Tabel 2. Pengaruh lama perendaman asam laktat terhadap kadar air, derajat putih, kadar protein dan kadar amilosa tepung koro pedang termodifikasi

\begin{tabular}{lllll}
\hline Lama perendaman & Kadar air $(\% \mathrm{wb})$ & Derajat putih $(\%)$ & Kadar protein $(\%)$ & Kadar amilosa $(\%)$ \\
\hline 0 menit & $7,701 \pm 0,185^{\mathrm{b}}$ & $85,757 \pm 0,407^{\mathrm{a}}$ & $28,947 \pm 0,567^{\mathrm{b}}$ & $25,276 \pm 0,182^{\mathrm{a}}$ \\
30 menit & $7,439 \pm 0,597^{\mathrm{ab}}$ & $86,923 \pm 0,467^{\mathrm{b}}$ & $25,104 \pm 1,432^{\mathrm{a}}$ & $27,301 \pm 0,527^{\mathrm{b}}$ \\
60 menit & $7,197 \pm 0,469^{\mathrm{a}}$ & $87,690 \pm 0,325^{\mathrm{c}}$ & $25,246 \pm 1,536^{\mathrm{a}}$ & $27,985 \pm 0,955^{\mathrm{b}}$ \\
\hline
\end{tabular}

Keterangan: angka yang diikuti huruf yang sama menunjukkan tidak berbeda nyata pada taraf signifikansi $\alpha=0,05$ 


\section{Kadar Protein}

Variasi perendaman asam laktat dapat menurunkan kandungan protein dalam koro pedang dibandingkan dengan kontrol. Hasil beda nyata ditunjukkan antar pelakuan kontrol dengan tepung termodifikasi, namun variasi konsentrasi asam laktat tidak berpengaruh nyata terhadap kadar protein tepung termodifikasi (Tabel 1). Penurunan protein yang terjadi pada tepung termodifikasi dikarenakan ion positif dari asam menyebabkan protein yang semula bermuatan netral menjadi bermuatan positif, ini menyebabkan kelarutan protein dalam air bertambah (Triyono, 2010).

Kadar protein tepung koro pedang termodifikasi mengalami penurunan dibandingkan dengan kontrol. Ophart, C.E. dalam Nurjanah (2008), mengemukakan bahwa semakin lama protein bereaksi dengan asam, kemungkinan besar ikatan peptida terhidrolisis sehingga struktur primer protein rusak. Menurut Anglemier dan Montglomery (1976), kadar protein turun karena lepasnya ikatan struktur protein selama perendaman sehingga komponen protein larut dalam air. Semakin lama waktu perendaman asam laktat, menyebabkan semakin banyak komponen protein yang larut air sehingga menurunkan kadar protein tepung.

\section{Kadar Amilosa}

Kadar amilosa tepung koro pedang termodifikasi berbeda nyata dan mengalami peningkatan apabila dibandingkan dengan perlakuan control (Tabel 1 dan Tabel 2). Kisaran amilosa tepung koro termodifikasi adalah $25,276-$ 27,816\%. Pati terdiri dari struktur amilosa dan amilopektin. Amilosa merupakan rantai lurus dan amilopektin merupakan rantai bercabang. Asam berperan dalam proses hidrolisis, sehingga memutuskan rantai pati. Pemutusan rantai pada proses hidrolisis lebih mudah terjadi pada amilopektin karena strukturnya bersifat amorf (renggang). Kandungan amilosa tepung koro pedang termodifikasi mengalami peningkatan dibandingkan dengan kontrol. Perlakuan hidrolisis dengan asam selain menghasilkan pemutusan pada rantai amilosa, juga terjadi pada sebagian rantai amilopektin, yang berakibat meningkatnya kandungan amilosa (Saguilan dkk., 2005).

\section{Daya Serap Air}

Konsentrasi asam laktat berpengaruh terhadap peningkatan daya serap air tepung koro pedang termodifikasi dibandingkan dengan kontrol (Tabel 3). Meningkatnya daya serap air pada tepung koro pedang termodifikasi diduga karena semakin tinggi konsentrasi asam yang ditambahkan menyebabkan asam yang terdifusi semakin banyak, atom $\mathrm{H}$ yang bereaksi dengan pati menjadikan ikatan hidrogen diantara pati lemah dan akibatnya ikatannya menjadi terputus. Menurut Asgar dan Musaddad (2006), terputusnya ikatan hidrogen menyebabkan daya serap air meningkat.

Pengaruh lama perendaman terhadap daya serap air tepung koro pedang termodifikasi terlihat pada Tabel 4. Nilai daya serap air tepung dengan perlakuan perendaman 60 menit mengalami kenaikan dibandingkan kontrol. Perendaman 30 menit tidak memberikan pengaruh pada kenaikan daya serap air.

\section{Kelarutan}

Semakin meningkatnya konsentrasi asam laktat yang diberikan, nilai kelarutan semakin besar. Pada tepung kontrol nilai kelarutan sebesar $32,985 \%$, berbeda nyata dengan semua tepung modifikasi. Tepung modifikasi dengan asam laktat $0,5 \%$ memiliki nilai kelarutan sebesar $35,160 \%$, tidak berbeda nyata dengan tepung koro pedang dengan asam laktat $1 \%$ yang memiliki nilai kelarutan sebesar $35,311 \%$. Tepung koro

Tabel 3. Pengaruh variasi konsentrasi asam laktat terhadap karakteristik fisikokimia tepung koro pedang termodifikasi

\begin{tabular}{llll}
\hline Konsentasi asam laktat (\%) & Daya serap air (ml/g) & Kelarutan $(\%)$ & Swelling power $(\mathrm{g} / \mathrm{g})$ \\
\hline $0 \%$ (kontrol) & $3,78 \pm 0,43^{\mathrm{a}}$ & $32,985 \pm 0,63^{\mathrm{a}}$ & $6,35 \pm 0,40^{\mathrm{a}}$ \\
$0,5 \%$ & $3,87 \pm 1,09^{\mathrm{bc}}$ & $35,160 \pm 1,49^{\mathrm{b}}$ & $6,83 \pm 0,25^{\mathrm{ab}}$ \\
$1 \%$ & $3,88 \pm 0,11^{\mathrm{bc}}$ & $35,311 \pm 1.18^{\mathrm{b}}$ & $7,33 \pm 0,54^{\mathrm{bc}}$ \\
$1,5 \%$ & $3,93 \pm 0,08^{\mathrm{c}}$ & $37,298 \pm 0,63^{\mathrm{c}}$ & $7,70 \pm 0,66^{\mathrm{c}}$ \\
\hline
\end{tabular}

Keterangan : angka yang diikuti huruf yang sama menunjukkan tidak berbeda nyata pada taraf signifikansi $\alpha=0,05$

Tabel 4. Pengaruh lama perendaman asam laktat terhadap karakteristik fisikokimia tepung koro pedang termodifikasi

\begin{tabular}{llll}
\hline Lama perendaman & Daya serap air $(\mathrm{ml} / \mathrm{g})$ & Kelarutan $(\%)$ & Swelling power $(\mathrm{g} / \mathrm{g})$ \\
\hline 0 menit & $3,78 \pm 0,43^{\mathrm{a}}$ & $32,985 \pm 0,63^{\mathrm{a}}$ & $6,35 \pm 0,40^{\mathrm{a}}$ \\
30 menit & $3,84 \pm 0,08^{\mathrm{a}}$ & $35,758 \pm 1,53^{\mathrm{b}}$ & $7,03 \pm 0,41^{\mathrm{b}}$ \\
60 menit & $3,96 \pm 0,07^{\mathrm{b}}$ & $36,093 \pm 1,49^{\mathrm{b}}$ & $7,55 \pm 0,68^{\mathrm{c}}$ \\
\hline
\end{tabular}

Keterangan : angka yang diikuti huruf yang sama menunjukkan tidak berbeda nyata pada taraf signifikansi $\alpha=0,05$ 
pedang modifikasi asam laktat $1,5 \%$ memiliki nilai kelarutan tertinggi yaitu sebesar $37,298 \%$, berbeda nyata dengan kelarutan pada perlakuan lain (Tabel 3). Menurut Demiate dkk. (2000), saat asam ditambahkan pada perendaman akan menyebabkan asam berdifusi ke granula pati, sehingga molekulnya menjadi lebih kecil dan mudah larut dalam air.

Semakin lama waktu reaksi yang digunakan, menghasilkan tepung koro pedang modifikasi dengan kelarutan yang semakin meningkat. Tepung dengan perendaman 60 menit memiliki nilai kelarutan tertinggi yaitu sebesar $36,09 \%$, tepung koro pedang dengan perendaman asam laktat 30 menit memiliki nilai kelarutan sebesar $35,76 \%$ dan tepung kontrol hanya memiliki kelarutan sebesar 32,99\% (Tabel 4). Menurut Pomeranz (1991), kelarutan pati semakin tinggi dengan meningkatnya suhu, serta kecepatan peningkatan kelarutan adalah khas untuk setiap pati. Waktu reaksi berpengaruh terhadap optimasi proses dan produk.

\section{Swelling Power}

Semakin tinggi konsentrasi asam laktat menyebabkan nilai swelling power semakin meningkat (Tabel 3). Swelling power terendah pada tepung kontrol yaitu sebesar $6,35 \mathrm{~g} / \mathrm{g}$ dan pada konsentrasi asam laktat sebesar 1,5\% memiliki nilai swelling power tertinggi yaitu sebesar 7,70 g/g. Peningkatan swelling power pada tepung modifikasi karena adanya hidrolisis pati. Hidrolisis terjadi karena adanya pemutusan rantai pati oleh asam.

Perendaman selama 0, 30, dan 60 menit mampu meningkatkan nilai swelling power. Swelling power tertinggi pada tepung koro pedang termodifikasi dengan perendaman asam laktat selama 60 menit adalah 7,55 g/g (Tabel 4). Semakin lama waktu perendaman asam, berarti semakin lama waktu hidrolisis, ini menyebabkan rantai pati tereduksi dan cenderung lebih pendek sehingga mudah menyerap air.

\section{KESIMPULAN}

Dari hasil penelitian dapat disimpulkan bahwa penggunaan konsentrasi asam laktat yang semakin besar dan semakin lamanya waktu perendaman mengakibatkan besarnya kandungan amilosa, daya serap air, kelarutan, swelling power, dan derajat putih tepung koro pedang termodifikasi semakin besar, tetapi akan menurunkan besarnya kadar air dan kadar protein tepung koro pedang termodifikasi.

\section{DAFTAR PUSTAKA}

Alsuhendra dan Ridawati (2009). Pengaruh Modifikasi secara Pregelatinisasi, Asam, dan Enzimatis terhadap Sifat Fungsional Tepung Umbi Gembili (Dioscorea esculenta). Program Studi Tata Boga. Fakultas Teknik. Universitas Negeri Jakarta, Jakarta.

Anglemier, A.E. dan Montgomery, M.W. (1976). Amino acids peptides and protein. Mercil Decker Inc., New York. Dalam: Triyono, A. 2010. Mempelajari Pengaruh Penambahan Beberapa Asam pada Proses Isolasi Protein terhadap Tepung Protein Isolat Kacang Hijau (Phaseolus Radiatus L.). Seminar Rekayasa Kimia dan Proses, Agustus 2010.

Apriyantono, A., Fardiaz, D. Puspitasari, N.L., Sedamawati dan Budiyanto, S. (1989). Analisis Pangan. PAU Pangan dan Gizi. IPB Press, Bogor.

Asgar, A. dan Musaddad, D. (2006). Optimalisasi Cara, Suhu dan Lama Blanching sebelum Pengeringan pada Wortel. Balai Penelitian Tanaman Sayuran Lembang. Bandung.

Dakornas (2012). Seminar Pengembangan Koro Pedang di Jawa Tengah di Fakultas Peternakan dan Pertanian Undip. Semarang, 26 November 2012.

Demiate, Dupuy, I.M. dan Huvenne, N. (2000). Relationship beetwen baking behaviour of modified cassava starch chemical structure determined by FTIR Spectroscopy. Carbohidrate Polymers 42: 149-158.

Disperindag. (2011). Tepung Terigu. Tim Komoditi Spesialis Tepung Terigu Kementerian Perdagangan Republik Indonesia. Jakarta.

Fardiaz, D. (1992). Analisis Mikrobiologi Pangan. Pusat Antar Universitas Pangan dan Gizi. Institut Pertanian Bogor, Bogor.

Harijono, Sari, T. dan Martati, E. (2008). Detoksifikasi umbi gadung (Dioscorea hispida Dennst.) dengan pemanasan terbatas dalam pengolahan tepung gadung. Jurnal Teknologi Pertanian 9(2): 75-82.

Leach, H.W., Mc Cowen, L.D. dan Schoch, T.J. (1959). Structure of the starch granules dalam Daramola, B. dan Osanyinlusi, S.A. (2006). Investigation on modification of cassava starch using active components of ginger roots (Zingiber officinale Roscoe). African Journal of Biotechnology 5(10): 917-920.

Mulyono, Y. (2012). Pemanfaatan Tepung Kacang Koro Pedang (Canavalia Ensiformis [L.] Dc) dan Tepung Beras Merah (Oryza Sativa Linn) pada Pembuatan Cookies Ditinjau dari Sifat Fisikokimia dan Sensori. Skripsi. Universitas Katolik Soegijapranata, Semarang.

Nurjanah (2008). Perubahan komposisi kimia dan vitamin daging udang ronggeng (Harpioquilla raphidea) akibat perebusan. Buletin Teknologi Hasil Perikanan XI(2): 76-88. 
Pomeranz, Y. (1991). Functional properties of Food component. Academic press, New York. Hal. 24-27.

Saguilan, AA., Flores-Huicochea, E., Tovar, J., GarciaSuarez, F., Gutierres-Meraz, F. dan Bello-Perez, LA. (2005). Resistant starch-rich powders prepared by autoclaving of native and lintnerized banana starch: partial characterization. Starch/Stärke 57: 405- 412.

Sudarmadji, S., Haryono, B. dan Suhardi (1997). Prosedur Analisis Bahan Makanan dan Pertanian. Liberty, Yogyakarta.

deMan, J.M. (1999). Kimia Makanan Edisi Kedua. Penerbit ITB, Bandung.

Triyono, A. (2010). Mempelajari pengaruh penambahan beberapa asam pada proses isolasi protein terhadap tepung protein isolat kacang hijau (Phaseolus radiatus L.). Seminar Rekayasa Kimia dan Proses, Agustus 2010.

Van der Maesen dan Somaatmadja (1993). Proses sumber daya nabati Asia Tenggara I. Gramedia Pustaka Utama, Jakarta. Dalam: Windrati, S.W., Nafi, A. dan Augustine, D.P. (2010). Sifat fungsional protein rich flour (PRF) koro pedang (Canavalia ensiformis L.). Jurnal Agrotek 4(1): 18-26.

Yanuwardana, Basito, dan Muhammad, D.R.A. (2013). Kajian karakteristik fisikokimia tepung labu kuning (Cucurbita moschata) termodifikasi dengan variasi lama perendaman dan konsentrasi asam laktat. Jurnal Teknosains Pangan 2(2): 75-83. 